\title{
変形制御機構を組込んだ柔剛混合構造における エネルギーの釣合に基づく応答予測法 \\ ENERGY BALANCE-BASED SEISMIC RESPONSE PREDICTION METHOD OF FLEXIBLE-STIFF MIXED STRUCTURE WITH DISPLACEMENT CONTROLLER
}

\author{
野村尚史*1, 佐藤大樹*2, 北村春幸*3, 植木卓也 ${ }^{* 4}$, 宮川和明*5 \\ Naoshi NOMURA, Daiki SATO, Haruyuki KITAMURA, \\ Takuya UEKI and Kazuaki MIYAGAWA
}

\begin{abstract}
It has been proven that the displacement controller which has hardening type hysteresis can reduce the displacement of frame or isolation layer against the huge earthquake from many experimental or analytical results. However, it is difficult to evaluate the changes in response characteristics with various qualitative parameters. The purpose of this paper is to evaluate the response characteristics of the flexible-stiff mixed structure with displacement controller qualitatively and simply. Energy balance-based seismic response prediction method proposed by Prof. Akiyama is extended to the structure with displacement controller, and this method is validated through many time history response analyses using the single-degree-of-freedom model. In addition, the estimation method for the passive controlled structure and the isolated structure with displacement controller is shown respectively, and the effectiveness of this method is demonstrated by analyzing time history analysis results and estimation results.
\end{abstract}

Keywords : Displacement Controller, Huge Earthquake, Flexible-Stiff Mixed Structure, SDOF Model, Energy Balance, Response Prediction Method

変形制御機構, 極大地震, 柔剛混合構造, 1 質点系モデル, エネルギーの釣合, 応答予測法

\section{1. はじめに}

従来の耐震設計は，主架構の塑性化により地震エネルギーを吸収 させることで建物の倒壊を回避し，人命を保護するという理念に基 づいていた。しかし，主架構が塑性化することで建物機能が失われ ることや，一部の部材もしくは層のエネルギー吸収能力によって建 物の耐震性が支配される等の問題点がある。これらの問題点は，小 さな剛性で弾性挙動をする柔要素と大きな剛性で弾塑性挙動をして 地震入力エネルギーを吸収する剛要素によって構成される柔剛混合 構造 ${ }^{1), 2)}$ の採用により解決される。柔剛混合構造の採用により合理 的な耐震設計が可能となるだけでなく, 主架構の損傷が抑制される ため地震後の改修が容易となる。また, 強度を確保する部材と地震 エネルギーを吸収する部材に明確に分離されるため, 柔要素として 高強度鋼，剛要素としてエネルギー吸収性能の高い低降伏点鋼を用 いるというように，材料の特性を生かした設計が可能となる。

1995 年の兵庫県南部地震では, 震度 7 クラスの地震動を起こす極 大地震（従来の想定を上回る大地震または地震動を起こす大地震を 極大地震と定義している）により甚大な建物被害が発生した ${ }^{3)} 。 こ$ れを機に, 柔剛混合構造の発想は損傷制御構造 ${ }^{4)}$ として広く認知さ れ, 地震時におけるエネルギーを効率的に吸収することが可能な制

*1 東京理科大学大学院理工学研究科建築学専攻 大学院生

*2 東京理科大学理工学部建築学科 助教 - 博士 (工学)

*3 東京理科大学理工学部建築学科 教授. 博士 (工学)

*4 JFE スチール(株) 主任研究員 (課長)

*5 JFE シビル(株) 開発グループ長・博士 (工学)
振構造が大幅に増加した ${ }^{5)}$ 。2 2011 年の東北地方太平洋沖地震では, マグニチュード 9.0 という想定以上の極大地震が発生した ${ }^{6}$ 。さら

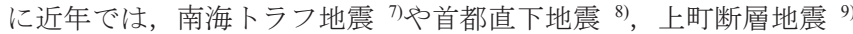
等の極大地震の発生が懸念されており，都市部において甚大な被害 が想定されている。以上のような従来の想定レベルを上回る地震動 に対しては，建物機能の維持を目的としてより高度な耐震性を持っ た建物例えば 10)が注目されるとともに，フェイルセーフを目的として 変形制御機構を導入する重要性が高まってきている。

変形制御機構については，ある変形以上の範囲で作用する硬化型 復元力特性を持つ機構として様々な研究がなされている。小堀ら ${ }^{11)}$ は, 非線形理論の角度から硬化型復元力特性を持つシステムを提案 し,解析的検討により 新耐震構造形式としての可能性を示している。 渡辺ら ${ }^{12-15)}$ は, 損傷集中の緩和を図る架構形式として周辺フレーム との間にギャップを設けたギャップ連層壁架構を提案し，損傷を分 散させ各層の最大層間変形を揃えることで，層崩壊防止にも有効で あるという地震時の応答特性を解析的に示している。井上ら ${ }^{16}$ は, 川股ら ${ }^{177}$ によて考案された硬化型復元力特性を有するエネルギー 吸収デバイスを 11 層 $\mathrm{RC}$ 造建物に用い, 多質点系モデルにおいてエ ネルギー応答に基づくとともに，鉄筋コンクリートの塑性状況を考

Graduate Student, Dept. of Architecture, Tokyo Univ. of Science Assist. Prof., Dept. of Architecture, Tokyo Univ. of Science, Dr. Eng. Prof., Dept. of Architecture, Tokyo Univ. of Science, Dr. Eng. JFE Steel Corporation

JFE Civil Engineering \& Construction Corporation, Dr. Eng. 
慮するために等価線形化法の考え方を取り入れ, 各層の応答塑性率 が目標值以下となるように必要なダンパー量とリミッターの適切な ギャップを簡便に算定する手法を提案することで, 各層の応答分布 形をスムーズにでき, 応答塑性率を目標值以下となったことを示し ている。林ら ${ }^{18)}$ は, 履歴系及び粘性系制振部材とある層間変形から 剛性を持ち始めるストッパーを考え, 1 質点系モデルと多質点系モ デルにおけるパルス性地震動に対する応答低隇効果として, 制振部 材とストッパーを適切に組合せることで応答を制御できる可能性が あることを示している。高橋ら ${ }^{19}$ は, 大地震時に発生する免震層の 過大な応答を制御することを目的として, ある変位から作用する水 平変位制御装置を免震層に組込むことで地震時の最大変位を低減さ せるとともに, その際の衝撃力に関しては上部構造の損傷はもとよ り家具類の転倒もないレベルまで抑えられることを実験及び応答解 析から示している。さらに飯場ら ${ }^{20), 21}$ は, 免震層のクリアランスが 十分大きく取れない免震住宅に着目して, 免震層の衝突が上部構造 の応答に及ぼす影響を振動台実験と解析から明らかにするとともに, 地震動, 免震システム, 変位抑制部材を変化させた応答解析結果の 分析から, 戸建て免震住宅の変位抑制設計法を提案している。

以上の研究では, 硬化型復元力特性を持つ変形制御機構を組込む ことで, 極大地震時の制振構造における架構及び免震構造における 免震層の最大変形を低減できることを実験的及び解析的に示してい るが，様々なパラメータによる応答特性の変化を定性的に評価する ことは困難である。よって本論文では, 高度な耐震性能を持った建 物として採用される制振構造及び免震構造に, 硬化型復元力特性を 有する変形制御機構を組込んだ変形制御構造の応答特性を定性的か つ簡便に評価することを目的とする。1 質点系モデルを対象として 秋山により提案されているエネルギーの釣合に基づく耐震設計法 ${ }^{22)}$ (以降, エネルギー法と表記) を, 柔剛混合構造に硬化型復元力特 性を有する変形制御機構を組込んだ変形制御構造に拡張し, 変形制 御構造におけるエネルギー法を提案する。また, 時刻歴応答解析に よる結果を用いて応答予測式を検証する。さらに, 変形制御機構を 組込んだ制振構造及び免震構造を対象として, 応答予測式を用いた 概略検討手法及び検討例を示し, 変形制御構造の応答特性として変 形低減に伴うせん断力増大の関係を明らかにする。

\section{2. 変形制御構造におけるエネルギー法の提案}

\section{1 変形制御構造の概要}

図 1 に変形制御構造の復元力特性を示し, 図 2 に 1 質点系の解析 モデルを示す。変形制御構造は, 建物の重力を支え弾性挙動する柔 要素 (flexible element), 地震エネルギーを吸収し弾塑性挙動をする 剛要素 (stiff element), ある変形から作用する硬化型復元力特性を示 寸変形制御機構 (displacement controller) で構成され, 変形制御機 構が作用しない $\left(\delta_{\max }<_{d} \delta_{g a p}\right)$ 場合 (図 1(i)) と作用する $\left(\delta_{\max }>_{d} \delta_{g a p}\right)$ 場合（図 1(ii)）に分けて復元力特性を考える。ここに， $\delta_{\max }$ は最大 変形, ${ }_{d} \delta_{g a p}$ は変形制御機構が作用し始める変形を表す。なお, 柔要 素及び変形制御機構は弾性挙動し, 剛要素は完全弾塑性型でモデル 化する。また, ${ }_{d} \delta_{g a p}$ は剛要素の降伏変形 ${ }_{s} \delta_{y}$ より大きい $\left({ }_{d} \delta_{g a p}>_{s} \delta_{y}\right)$ ことが前提である。また, 変形の全てが剛要素の変形に寄与するこ ととし, 剛要素の変形の伝達を損なう全体曲げ変形等の影響は別途 考慮する必要がある ${ }^{23) 。 ~}$

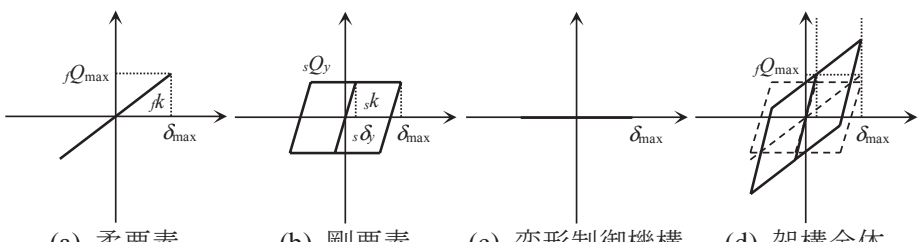

(a) 柔要素

(b) 剛要素

(c) 変形制御機構

(d) 架構全体 (i) 変形制御機構が作用しない場合 $\left(\delta_{\max }<{ }_{d} \delta_{g a p}\right)$

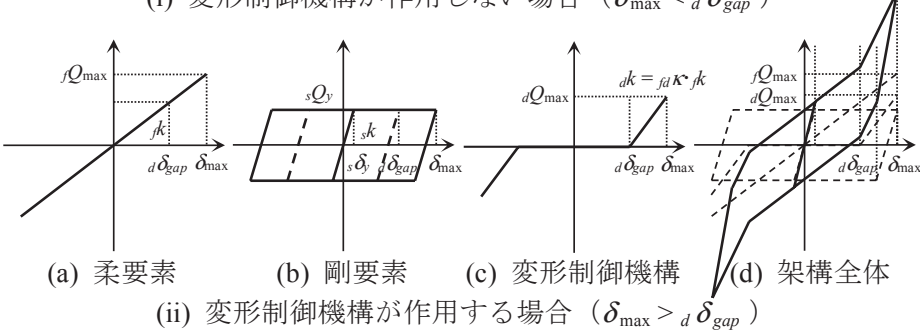

図 1 変形制御構造の復元力特性

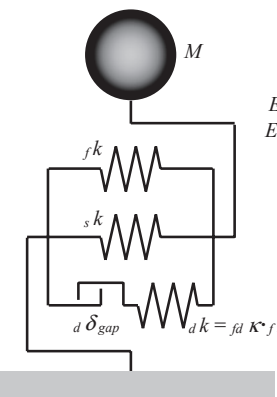

図 2 解析モデル

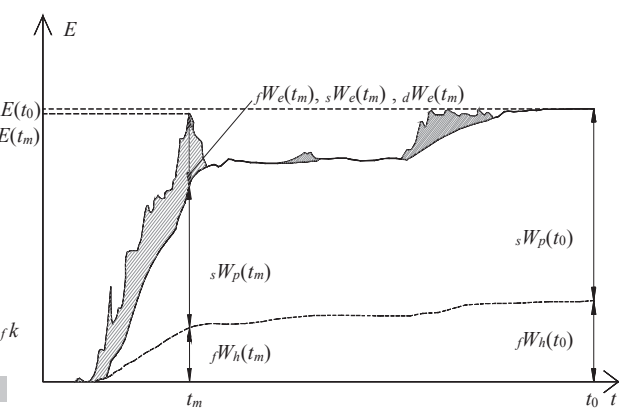

図 3 エネルギーの時刻歴応答の模式図

\section{2 変形制御構造における応答予測式の導出}

図 3 に変形制御構造におけるエネルギーの時刻歷応答の模式図を 示す。横軸は地震動の開始時刻からの時刻 $t$ を表し, 時刻 $t_{m}$ は建物 の最大応答值発生時刻, 時刻 $t_{0}$ は地震動の継続時間を表す。 ${ }_{f} W_{e}(t),{ }_{f} W_{h}(t)$ は柔要素の弾性振動エネルギー及び減衰による消費 エネルギー, ${ }_{s} W_{e}(t),{ }_{s} W_{p}(t)$ は剛要素の弾性振動エネルギー及び塑性 履歴エネルギー, ${ }_{d} W_{e}(t)$ は変形制御機構の弾性振動エネルギーを表 す。図 3 より, ${ }_{f} W_{e}(t),{ }_{s} W_{e}(t),{ }_{d} W_{e}(t)$ は $t=t_{m}$ で最大值となり, $t=t_{0}$ で ほとんど消滅する。 $E(t)$ は入力エネルギーを表し， $E(t)-{ }_{f} W_{h}(t)$ を損 傷に寄与するエネルギー $E_{D}(t)$ と定義する ${ }^{22)}$ 。

変形制御構造の目的は, 極大地震に対して過大な変形が生じるの を制御することであるため, 本論文では最大応答值発生時刻 $t_{m}$ に着 目してエネルギーの釣合 ${ }^{24)}$ 考える。免震構造や制振構造では，免 震・制振部材の塑性履歴エネルギーや減衰エネルギーが入力エネル ギーに占める割合は高くなり, 一般に $E\left(t_{m}\right) \leq E\left(t_{0}\right)$ となる。入力エ ネルギーを大きく評価することは応答の安全側の評価に繋がること から, 変形制御構造においても $E_{D}\left(t_{m}\right)$ を $E_{D}\left(t_{0}\right)$ に置き換えると, $t=t_{m}$ におけるエネルギーの釣合式は下式のように表せる。

$$
\begin{array}{ll}
{ }_{f} W_{e}\left(t_{m}\right)+{ }_{s} W_{p}\left(t_{m}\right)=E_{D}\left(t_{0}\right) & \left(\delta_{\max }<_{d} \delta_{g a p}\right) \\
{ }_{f} W_{e}\left(t_{m}\right)+{ }_{s} W_{p}\left(t_{m}\right)+{ }_{d} W_{e}\left(t_{m}\right)=E_{D}\left(t_{0}\right) & \left(\delta_{\max }>_{d} \delta_{g a p}\right)
\end{array}
$$
${ }_{s} W_{e}\left(t_{m}\right)$ は $E_{D}\left(t_{0}\right)$ に対して十分に小さいため $\left.{ }^{25}\right)$ 無視することとする。

以下に, 1 質点系モデルを対象として, 式(1)で用いられる各要素 のエネルギーの算出式を示す。

損傷に寄与するエネルギー $E_{D}\left(t_{0}\right)$ は下式で表される ${ }^{22)}$ 


$$
E_{D}\left(t_{0}\right)=\frac{M \cdot V_{D}^{2}}{2}
$$

ここに, $M$ : 質量, $V_{D}: E_{D}$ の速度換算値 ${ }^{22)}$ である。

柔要素の弾性振動エネルギー ${ }_{f} W_{e}\left(t_{m}\right)$ は下式で表される。

$$
\begin{aligned}
{ }_{f} W_{e}\left(t_{m}\right) & =\frac{{ }_{f} Q_{\max } \cdot \delta_{\max }}{2}=\frac{{ }_{f} Q_{\max }{ }^{2}}{2 \cdot{ }_{f} k} \\
& =\frac{\left({ }_{f} \alpha_{\max } \cdot M \cdot g\right)^{2}}{2} \frac{{ }_{f} T_{1}^{2}}{4 \pi^{2} \cdot M}=\frac{M \cdot V_{D}{ }^{2}}{2}\left(\frac{{ }_{f} \alpha_{\max }}{{ }_{f} \alpha_{0}}\right)^{2}
\end{aligned}
$$

ここで, $\delta_{\max }=\frac{{ }_{f} Q_{\max }}{{ }_{f} k},{ }_{f} \alpha_{\max }=\frac{{ }_{f} Q_{\max }}{M \cdot g},{ }_{f} k=\frac{4 \pi^{2} \cdot M}{{ }_{f} T_{1}^{2}},{ }_{f} \alpha_{0}=\frac{2 \pi \cdot V_{D}}{{ }_{f} T_{1} \cdot g}$

$(4 \mathrm{a} \sim \mathrm{d})$

ここに, ${ }_{f} Q_{\max }$ : 柔要素の最大せん断力, $\delta_{\max }$ : 最大変形, ${ }_{f} k$ : 柔 要素の剛性, $g$ : 重力加速度, ${ }_{f} \alpha_{\max }$ : 柔要素の最大せん断力係数, ${ }_{f} T_{1}$ : 柔要素のみの場合の 1 次固有周期, ${ }_{f} \alpha_{0}$ : 柔要素の夕の場合 の最大せん断力係数である。

剛要素の塑性履歴エネルギー ${ }_{s} W_{p}\left(t_{m}\right)$ は, 剛要素の等価繰返し数 $n_{1}$ を用いて下式で表される。

$$
\begin{aligned}
{ }_{s} W_{p}\left(t_{m}\right)= & 4 n_{1} \cdot{ }_{s} Q_{y} \cdot\left(\delta_{\max }-{ }_{s} \delta_{y}\right) \cong 4 n_{1} \cdot{ }_{s} Q_{y} \cdot \delta_{\max }=4 n_{1} \cdot \frac{{ }_{s} Q_{y} \cdot{ }_{f} Q_{\max }}{{ }_{f} k} \\
& =4 n_{1} \cdot\left({ }_{s} \alpha_{y} \cdot M \cdot g\right)\left({ }_{f} \alpha_{\max } \cdot M \cdot g\right) \frac{{ }_{f} T_{1}{ }^{2}}{4 \pi^{2} \cdot M} \\
& =\frac{M \cdot V_{D}{ }^{2}}{2} \cdot 8 n_{1} \cdot\left(\frac{{ }_{s} \alpha_{y}}{{ }_{f} \alpha_{0}}\right)\left(\frac{{ }_{f} \alpha_{\max }}{{ }_{f} \alpha_{0}}\right)
\end{aligned}
$$

ここで, $\quad \delta_{\max }-{ }_{s} \delta_{y} \cong \delta_{\max },{ }_{s} \alpha_{y}=\frac{{ }_{s} Q_{y}}{M \cdot g}$

ここに, ${ }_{s} Q_{y}$ : 剛要素の降伏せん断力, ${ }_{s} \delta_{y}$ : 剛要素の降伏変形,

${ }_{s} \alpha_{y}$ : 剛要素の降伏せん断力係数である。変形制御構造では, 変形 制御機構が作用することで, 剛要素のエネルギー吸収効率が低下寸 ることが予想されるが, 変形制御機構が作用する時間は地震動の継 続時間と比較してわずかであるため ${ }^{26)}$, 本論文では変形制御機構の 有無に関わらず同様の $n_{1}$ を用いることとした。

変形制御機構の弾性振動エネルギー ${ }_{d} W_{e}\left(t_{m}\right)$ は下式で表される。

$$
{ }_{d} W_{e}\left(t_{m}\right)=\frac{{ }_{d} Q_{\max } \cdot\left(\delta_{\max }-{ }_{d} \delta_{g a p}\right)}{2}=\frac{{ }_{d} Q_{\max }{ }^{2}}{2 \cdot d}=\frac{M \cdot V_{D}{ }^{2}}{2 \cdot f d} \kappa\left(\frac{{ }_{d} \alpha_{\max }}{{ }_{f} \alpha_{0}}\right)^{2}
$$

ここで, ${ }_{d} k=\frac{{ }_{d} Q_{\max }}{\delta_{\max }-d \delta_{g a p}},{ }_{d} \alpha_{\max }=\frac{{ }_{d} Q_{\max }}{M \cdot g},{ }_{f d} \kappa={ }_{d} k /{ }_{f} k$

ここに, ${ }_{d} Q_{\max }$ : 変形制御機構の最大せん断力, ${ }_{d} \delta_{g a p}:$ 変形制御機 構が作用し始める変形, ${ }_{d} k$ : 変形制御機構の剛性, ${ }_{d} \alpha_{\max }$ : 変形制 御機構の最大せん断力係数, $f d \boldsymbol{\kappa}$ : 柔要素の剛性 $f k$ に対寸る変形制 御機構の剛性 ${ }_{d} k$ の割合である。式(4a), (8a)を式(8c)に代入し, ${ }_{d} \alpha_{\text {max }} /{ }_{f} \alpha_{0}$ について解くと下式が得られる。

$$
\begin{aligned}
& \frac{{ }_{d} \alpha_{\max }}{{ }_{f} \alpha_{0}}={ }_{f d} \kappa \cdot\left(\frac{{ }_{f} \alpha_{\max }}{{ }_{f} \alpha_{0}}-\frac{{ }_{d} \delta_{g a p}}{{ }_{f} \delta_{0}}\right) \\
& \text { ここで, }{ }_{f} \delta_{0}=\frac{{ }_{f} T_{1} \cdot V_{D}}{2 \pi}
\end{aligned}
$$

ここに, ${ }_{f} \delta_{0}:$ 柔要素のみの場合の最大変形である。式(9)を式(7) に代入すると, 最終的に ${ }_{d} W_{e}\left(t_{m}\right)$ は次式で表される。

$$
{ }_{d} W_{e}\left(t_{m}\right)=\frac{M \cdot V_{D}{ }^{2}}{2} \cdot{ }_{f d} \kappa \cdot\left(\frac{{ }_{f} \alpha_{\max }}{{ }_{f} \alpha_{0}}-\frac{{ }_{d} \delta_{g a p}}{{ }_{f} \delta_{0}}\right)^{2}
$$

変形制御機構が作用する場合において, 応答予測式を導出する。 式(1b)に式(2)，(3)，(5)，(11)の各要素のエネルギーを代入すると下式 が得られる。

$$
\left(\frac{{ }_{f} \alpha_{\max }}{{ }_{f} \alpha_{0}}\right)^{2}+8 n_{1} \cdot\left(\frac{{ }_{s} \alpha_{y}}{{ }_{f} \alpha_{0}}\right)\left(\frac{{ }_{f} \alpha_{\max }}{{ }_{f} \alpha_{0}}\right)+{ }_{f d} \kappa \cdot\left(\frac{{ }_{f} \alpha_{\max }}{{ }_{f} \alpha_{0}}-\frac{{ }_{d} \delta_{g a p}}{{ }_{f} \delta_{0}}\right)^{2}=1
$$

$\delta_{\max } /{ }_{f} \delta_{0}$ は式(4a)に式(4b), (4c)を代入し, 式(10)で除すことにより 下式で表される。

$$
\frac{\delta_{\max }}{{ }_{f} \delta_{0}}=\frac{{ }_{f} \alpha_{\max } \cdot M \cdot g \cdot{ }_{f} T_{1}^{2}}{4 \pi^{2} \cdot M} \cdot \frac{2 \pi}{{ }_{f} T_{1} \cdot V_{D}}=\frac{{ }_{f} \alpha_{\max }}{{ }_{f} \alpha_{0}}
$$

各要素のせん断力係数と剛要素の降伏せん断力係数の関係式を導 出する。式(12)を ${ }_{f} \alpha_{\max } /{ }_{f} \alpha_{0} \quad\left(=\delta_{\max } /{ }_{f} \delta_{0}\right)$ について解くと下式が得 られる。

$$
\begin{aligned}
& \frac{{ }_{f} \alpha_{\max }}{{ }_{f} \alpha_{0}}=\frac{\delta_{\max }}{{ }_{f} \delta_{0}} \\
& =\frac{1}{1+{ }_{f d} \kappa}\left[+\sqrt{-4 n_{1} \cdot \frac{{ }_{s} \alpha_{y}}{{ }_{f} \alpha_{0}}+{ }_{f d} \kappa \cdot \frac{{ }_{d} \delta_{g a p}}{{ }_{f} \delta_{0}}}\right.
\end{aligned}
$$

式(14)より, 架構全体の最大せん断力係数 $\alpha_{\text {max }}$ を ${ }_{f} \alpha_{0}$ で除した $\alpha_{\max } /{ }_{f} \alpha_{0}$ は下式で表される。

$$
\begin{aligned}
& \frac{\alpha_{\max }}{{ }_{f} \alpha_{0}}=\frac{{ }_{f} \alpha_{\max }}{{ }_{f} \alpha_{0}}+\frac{{ }_{s} \alpha_{y}}{{ }_{f} \alpha_{0}}+\frac{{ }_{d} \alpha_{\max }}{{ }_{f} \alpha_{0}}
\end{aligned}
$$

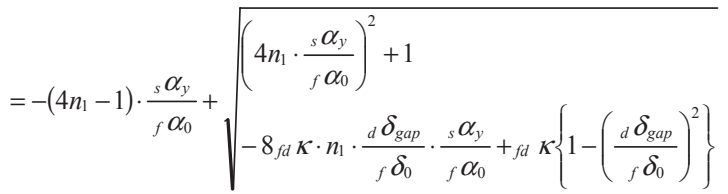

式(12)に式(13)を代入し， ${ }_{s} \alpha_{y} /{ }_{f} \alpha_{0}$ 及び $\alpha_{\max } /{ }_{f} \alpha_{0}$ について解くと, 各要素のせん断力係数と最大変形の関係式が導出される(附録 $\mathrm{A}$ 参 照)。なお, 式(12),(14),(15)において $f d K=0$ とすると, 変形制御機 構が作用しない場合の応答予測式が導出され, これは柔剛混合構造 の応答予測式に一致する。

\section{3. 時刻歴応答解析による応答予測式の検証}

\section{1 解析モデル及び入力地震動の概要}

前章で導出した応答予測式を, 変形制御機構を組込んだ変形制御 構造モデルの時刻歴応答解析から検証する。ここでは, 1 質点系制 振・免震構造モデルを対象とする。制振構造モデルにおける柔要素 は主架構であり,免震構造モデルにおける柔要素は積層ゴムである。 表 1 に解析パラメータを示す。時刻歴応答解析は 1 質点系モデルを 対象として, 質量 $M$ を 100 ton で一定とし, 柔要素の 1 次固有周期 ${ }_{f} T_{1}$, 剛要素の降伏せん断力係数 $\alpha_{s}$, 変形制御機構が作用し始める変形 ${ }_{d} \delta_{g a p}$ を ${ }_{f} \delta_{0}$ で除した ${ }_{d} \delta_{g a p} /{ }_{f} \delta_{0}$, 柔要素の剛性 ${ }_{f} k$ に対する変形制御 機構の剛性 ${ }_{d} k$ の割合 ${ }_{f d} \kappa$, 損傷に寄与寸るエネルギー $E_{D}$ の速度換 算值 $V_{D}$ をパラメータとして設定する。

なお本解析では, 制振構造モデルでは主架構の構造減衰, 免震構 造モデルでは免震層に粘性減衰型ダンパーを設置することを想定し， 解析モデルの減衰は柔要素の周期 $f_{1}$ に対して ${ }_{f} h=0.02$ となる剛性 
比例型で設定する。

制振構造モデルは, 主架構の 1 次固有周期 ${ }_{f} T_{1}$ を $1.0,2.0 \mathrm{~s}$ とする。 ここでは, 1 質点系モデルの建物高さ $H$ を $33 \mathrm{~m}$ で一定とし, ${ }_{f} T_{1}=$ $0.03 H, 0.06 H$ と一般的な鋼構造建物及び高強度鋼を用いた岡性の低 (鋼構造建物 27) 想定する。 ${ }_{s} \alpha_{y}=0.02 \sim 0.15,{ }_{d} \delta_{g a p} /{ }_{f} \delta_{0}=0.2,0.4$, ${ }_{f d} \boldsymbol{K}=1.0,4.0$ を検討に用いる。1 質点系モデルの等価建物高さ $H_{e q}$ は 2/3H (= $22 \mathrm{~m})$ と設定し, 主架構は弾性挙動をすることとする。 ダンパーは塑性化部に LY225 を用いた座屈拘束ブレースを階高 $4 \mathrm{~m}$ の $6 \mathrm{~m}$ スパンに八の字 (角度 $53^{\circ}$ ) で組込むことを想定し, 降伏変 形 ${ }_{s} \delta_{y}$ は $6.10 \mathrm{~mm}$ となるため, ダンパーの降伏変形角 ${ }_{s} R_{y}$ は $1 / 656 \mathrm{rad}$ となる。想定しているダンパーは塑性化部と弾性部で構成されるが, 解析上は等価なヤング係数を用いて 1 要素（一様断面）でモデル化

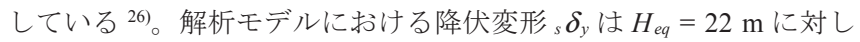
て $33.5 \mathrm{~mm}$ となる。1 次固有周期 $T_{1} T_{1}=1.0 \mathrm{~s}$ の時の解析モデルにおけ る主架構の剛性 $f k$ は $3.95 \times 10^{3} \mathrm{kN} / \mathrm{m}$ となり, 変形制御機構の剛性 ${ }_{d} k$ は $3.95 \times 10^{3} \mathrm{kN} / \mathrm{m}, 3.16 \times 10^{4} \mathrm{kN} / \mathrm{m}$ となる。免震構造モデルは ${ }_{f} T_{1}=$ $3.0,4.0 \mathrm{~s}$ 想定し $,{ }_{s} \alpha_{y}=0.01 \sim 0.10,{ }_{d} \delta_{g a p} / f \delta_{0}=0.2,0.4, \quad{ }_{f d} \kappa=20$ と設定する。ダンパーは鋼材ダンパーを使用することを想定するた め, 降伏変形 ${ }_{s} \delta_{y}$ は $27.9 \mathrm{~mm}{ }^{28)}$ である。1 次固有周期 ${ }_{f} T_{1}=3.0 \mathrm{~s}$ の時 の解析モデルにおける主架構の剛性 ${ }_{f} k$ は $0.439 \times 10^{3} \mathrm{kN} / \mathrm{m}$ となり, 変形制御機構の剛性 ${ }_{d} k$ は $8.78 \times 10^{3} \mathrm{kN} / \mathrm{m}$ となる。

図 4 に地震動の擬似速度応答スペクトル ${ }_{p} S_{v} \quad(h=0.05)$ とエネル ギースペクトル $V_{E}(h=0.10)$ を示し, 図 5 に地震動の加速度時刻

\begin{tabular}{|c|c|c|}
\hline & 制振構造 & 免震構造 \\
\hline $\begin{array}{l}\text { 柔要素の } \\
\text { 1次固有周期 }{ }_{f} T_{1}(\mathrm{~s})\end{array}$ & $1.0,2.0$ & $3.0,4.0$ \\
\hline $\begin{array}{l}\text { 剛要素の } \\
\text { 降伏せん断力係数 }{ }_{s} \alpha_{y}\end{array}$ & $0.02,0.04,0.08,0.12,0.15$ & $0.01,0.02,0.04,0.06,0.10$ \\
\hline $\begin{array}{l}\text { 変形制御機構が } \\
\text { 作用し始める変形 }{ }_{d} \delta_{\text {gap }} / f \delta_{0}\end{array}$ & $0.2,0.4$ & $0.2,0.4$ \\
\hline $\begin{array}{l}\text { 柔要素の剛性に対する } \\
\text { 変形制御機構の剛性比 }{ }_{f d} \kappa \\
\end{array}$ & $1.0,4.0$ & 20.0 \\
\hline 損傷に寄与するエネルギーの & ART KOBE & $100,200,300$ \\
\hline 速度換算値 $V_{D}(\mathrm{~cm} / \mathrm{s})$ & ART SHIN & $250,500,750$ \\
\hline
\end{tabular}

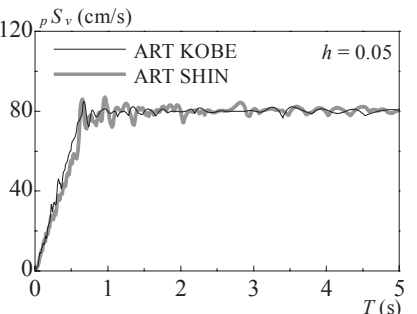

(a) 擬似速度応答スペクトル

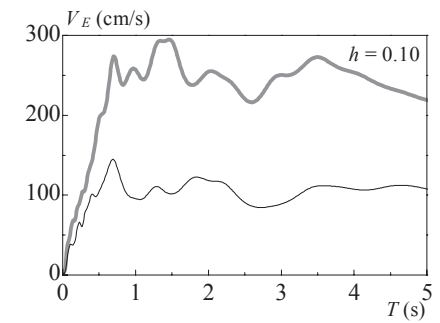

(b) エネルギースペクトル

$\left({ }_{p} S_{v}=80 \mathrm{~cm} / \mathrm{s}\right)$

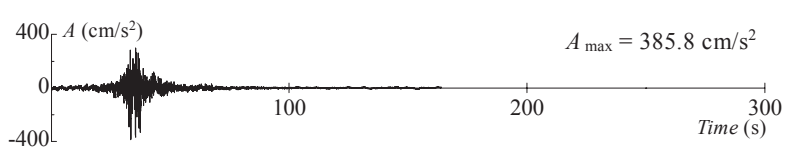

(a) ART KOBE

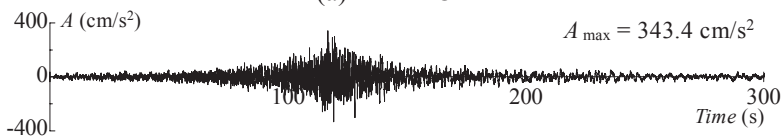

(b) ART SHIN

図 5 地震動の加速度時刻歴波形 $\left({ }_{p} S_{v}=80 \mathrm{~cm} / \mathrm{s}\right)$
歴波形を示す。入力地震動には，告示スペクトルに一致するように 作成された模擬波を用い, コーナー周期 $T_{c} \geq 0.64 \mathrm{~s}$ において ${ }_{p} S_{v}$ が一 定となるように設定する。位相特性は, 最大応答值が大きいことか ら超高層建物や免震建物の設計で一般的に用いられる JMA KOBE 1995 NS と, K-net 観測点のうち東北地方太平洋沖地震本震における 東京都新宿地区（TKY007）での観測波とし，ART KOBE 及びART SHIN と表記している。図 4, 5 には, ${ }_{p} S_{v}$ が $80 \mathrm{~cm} / \mathrm{s}$ で一定となる場 合を示している。本解析では，ART KOBE において損傷に寄与する エネルギーの速度換算値 $V_{D}=100 \mathrm{~cm} / \mathrm{s}$ を極めて稀に作用する地震 動レベルと定義し， $V_{D}=100,200,300 \mathrm{~cm} / \mathrm{s}$ をパラメータとする。ART SHIN においては $V_{D}=250 \mathrm{~cm} / \mathrm{s}$ を極めて稀に作用する地震動レベル と定義し， $V_{D}=250,500,750 \mathrm{~cm} / \mathrm{s}$ をパラメータとする。表 1 に解析 パラメータを示す。各解析ケースにおいて，損傷に寄与するエネル ギーの速度換算值 $V_{D}$ の解析值が表 1 に示した $V_{D}$ と同程度となるよ うに入力加速度倍率を調整して解析を行う。

\section{2 解析値と予測值の比較及び応答予測式の検証}

2.2 節で導出した応答予測式による予測值と 1 質点系モデルでの 時刻歴応答解析による解析値の比較により, 変形制御機構が作用す る場合の応答予測式である式(14), (15)を検証する。表 1 の解析パラ メータに変形制御機構を組込まない場合 (no controller) を加え, 最 大加速度をレベル 2 地震動に対して 1.0, 2.0, 3.0 倍とした模擬波によ る解析を行う。等価繰返し数 $n_{1}$ は地震動の継続時間に比例して増加 する傾向を示す。免震構造では, EL CENTRO NS に対して $n_{1}=2.0$ が下限值として設定されている ${ }^{22)}$ ここでは, 継続時間の短い ART KOBE と長い ART SHIN を採用していることから, 表 1 の解析パラ メータを用いた各地震動による解析結果から $n_{1}$ を求め, その結果に

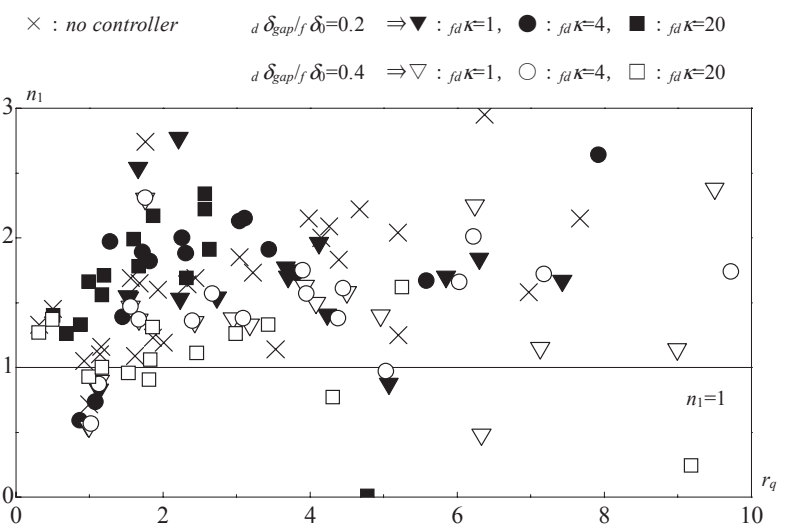

(a) ART KOBE

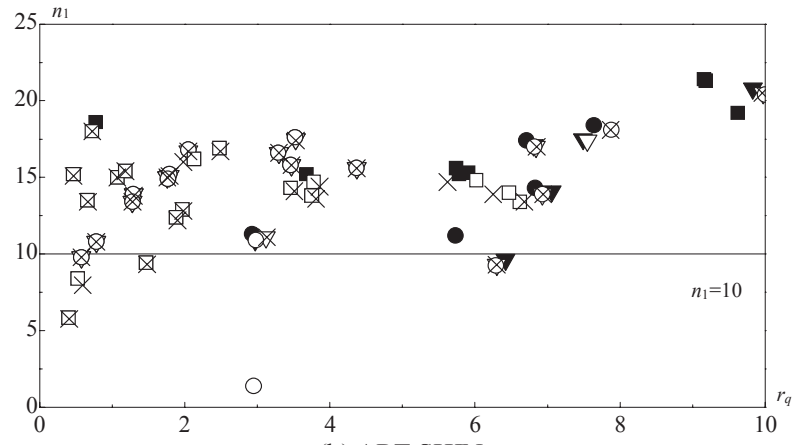

(b) ART SHIN

図 $6 n_{1}$ と $r_{q}$ の関係 
基づき予測值の算定に採用する $n_{1}$ を設定することとする。解析結果 を下式に代入して，等価繰返し数 $n_{1}$ を求める。

$$
n_{1}=\frac{E_{D}\left(t_{0}\right)-\left\{{ }_{f} W_{e}\left(t_{m}\right)+{ }_{d} W_{e}\left(t_{m}\right)\right\}}{4_{s} Q_{y} \cdot\left(\delta_{\max }-{ }_{s} \delta_{y}\right)}
$$

図 6(a), (b)に, 柔要素の最大せん断力 ${ }_{f} Q_{\text {max }}$ と剛要素の降伏せん断 力 ${ }_{s} Q_{y}$ の比である $\left.r_{q}{ }^{22}\right)$ と等価繰返し数 $n_{1}$ の関係を示す。図 6(a) より, ART KOBE の $n_{1}$ は $r_{q}$ が 1.0 以上において概子 $1.0 \sim 3.0$ の範囲に分布 しており，ここでは下限值の $n_{1}=1.0$ を採用する。図 6(b)より, ART SHIN の $n_{1}$ は $r_{q}$ が 1.0 以上において概衫 10〜20の範囲に分布してお り, ここでは下限值の $n_{1}=10$ を採用することとする。予測值は, ${ }_{s} \alpha_{y}$ をパラメータとして式(14)より $\delta_{\max } /{ }_{f} \delta_{0}\left({ }_{f_{f}} \alpha_{\max } /{ }_{f} \alpha_{0}\right)$, 式(15)より $\alpha_{\text {max }} /{ }_{f} \alpha_{0}$ を算出する。

図 7(a), (b)に, 式(15)で表される $\alpha_{\max } /{ }_{f} \alpha_{0}$ と ${ }_{s} \alpha_{y} /{ }_{f} \alpha_{0}$ の関係式に表 1 の解析パラメータに基づく解析值をプロットしたものを示す。太 破線は変形制御機構を組込まない場合の $\alpha_{\max } /{ }_{f} \alpha_{0}$ であり, no controller と表記している。右上に単調増加している細実線は ${ }_{s} \alpha_{y} /{ }_{f} \alpha_{0}$, 右下に減少している細実線は式(14)の ${ }_{f} \alpha_{\max } /{ }_{f} \alpha_{0}$ を示す。 太実線は ${ }_{d} \delta_{g a p} /{ }_{f} \delta_{0}=0.2,0.4$ の場合の変形制御機構が作用している 場合の $\alpha_{\max } /{ }_{f} \alpha_{0}$ を示し, それぞれ ${ }_{s} \alpha_{y} /{ }_{f} \alpha_{0}>0$ の範囲について示す こととする。
図 8(a), (b)に, 附録 $\mathrm{A}$ の式(A2)で表される $\alpha_{\max } /{ }_{f} \alpha_{0}$ と $\delta_{\max } /{ }_{f} \delta_{0}$ の 関係式に同様の解析值をプロットしたものを示寸。太破線は変形制 御機構を組込まない場合の $\alpha_{\max } /{ }_{f} \alpha_{0}$ であり, 右上に単調増加してい る細実線は式(13)の ${ }_{f} \alpha_{\text {max }} /{ }_{f} \alpha_{0}$, 右下に減少している細実線は式(A1) の ${ }_{s} \alpha_{y} /{ }_{f} \alpha_{0}$ を示す。太実線は ${ }_{d} \delta_{g a p} /{ }_{f} \delta_{0}=0.2,0.4$ の場合の変形制御 機構が作用している時の $\alpha_{\max } /{ }_{f} \alpha_{0}$ を示し，それぞれ ${ }_{s} \alpha_{y} /{ }_{f} \alpha_{0}>0$ の 範囲について示寸こととする。図 7,8 中の $\nabla, \bigcirc, \square か ゙$ 解析結果を 示す。白抜きの凡例が ${ }_{d} \delta_{g a p} /{ }_{f} \delta_{0}=0.4$ の場合, 中塗りの凡例が ${ }_{d} \delta_{g a p} /{ }_{f} \delta_{0}=0.2$ の場合の解析值を示す。 $\nabla, \bigcirc, \square$ ぞれぞれ ${ }_{f d} \kappa=1.0$, 4.0,20の場合の解析值を示す。

図 7,8(a), (b)より, 応答予測式は ART KOBE 及び ART SHIN によ る解析值の傾向と良く一致しており，概称解析值を上回る安全側の 評価になっている。また, 変形制御機構を組込まない場合（no controller) は, 最大せん断力 $\alpha_{\text {max }} /{ }_{f} \alpha_{0}$ が最小となる最適值が存在し, それを $n_{1}=1.0$ の場合の予測式から求めると, ${ }_{s} \alpha_{y} /{ }_{f} \alpha_{0}=0.28$, ${ }_{f} \alpha_{\max } /{ }_{f} \alpha_{0}=\delta_{\max } /{ }_{f} \delta_{0}=0.38$ の時に $\alpha_{\max } /{ }_{f} \alpha_{0}=0.66$ が最小值となる。 同様に, $n_{1}=10$ の場合は, ${ }_{f} \alpha_{\max } /{ }_{f} \alpha_{0}=\delta_{\max } /{ }_{f} \delta_{0}={ }_{s} \alpha_{y} /{ }_{f} \alpha_{0}=0.11$ の 時に $\alpha_{\text {max }} /{ }_{f} \alpha_{0}=0.22$ が最小值となる。 $n_{1}=1.0$ の場合の予測式及び ART KOBE の解析值では, 変形制御機構が作用し始める変形が ${ }_{d} \delta_{g a p} /{ }_{f} \delta_{0}=0.2$ の時, 最適値となる変形 $\delta_{\max } /{ }_{f} \delta_{0}=0.38$ に達する前

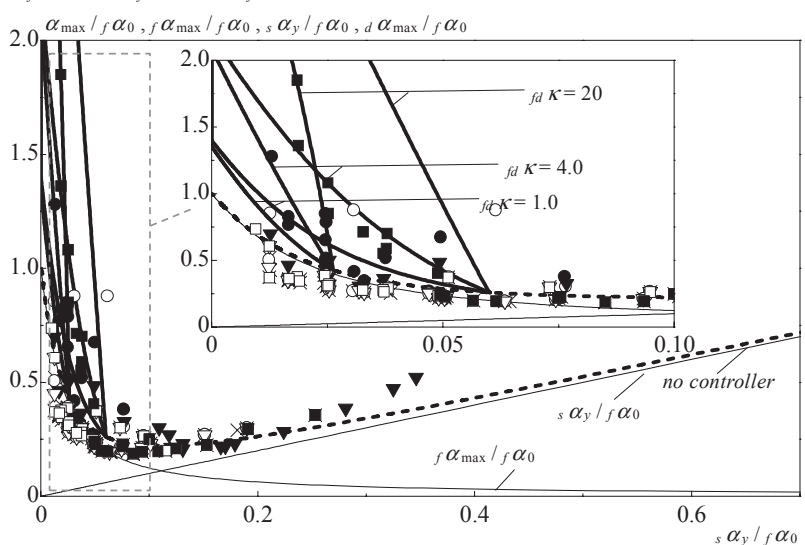

(b) ART SHIN $\left(n_{1}=10\right)$

(a) ART KOBE $\left(n_{1}=1.0\right)$

図 $7 \alpha_{\max } /{ }_{f} \alpha_{0}$ と ${ }_{s} \alpha_{y} /{ }_{f} \alpha_{0}$ の関係

$\times$ : no controlle

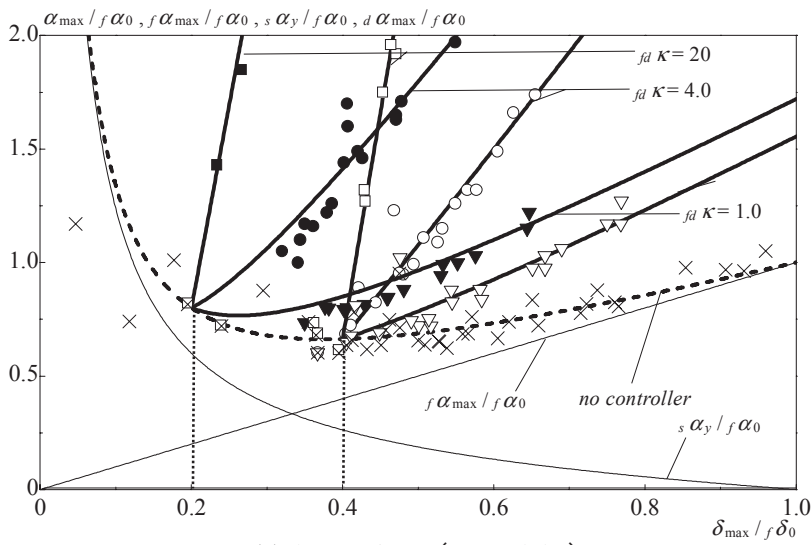

(a) ART KOBE $\left(n_{1}=1.0\right)$

${ }_{d} \delta_{\text {gap }} / f \delta_{0}=0.4$
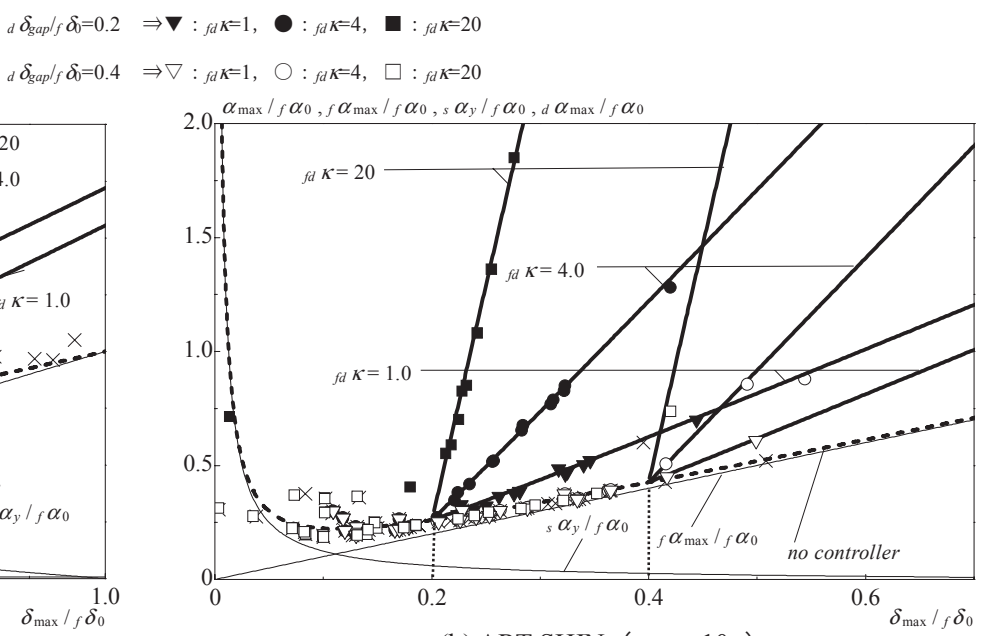

(b) ART SHIN $\left(n_{1}=10\right)$

図 $8 \quad \alpha_{\max } /{ }_{f} \alpha_{0}$ と $\delta_{\max } /{ }_{f} \delta_{0}$ の関倸 
に変形制御機構が作用し, 最大せん断力 $\alpha_{\max } /{ }_{f} \alpha_{0}$ が急激に増加する。 ${ }_{d} \delta_{g a p} /{ }_{f} \delta_{0}=0.4$ の時, 最適值となる変形を越えてから変形制御機構 が作用し, 最大せん断力 $\alpha_{\max } /{ }_{f} \alpha_{0}$ が急激に増加する。 $n_{1}=10$ の場合 の予測值及びART SHIN の解析值では, ${ }_{d} \delta_{g a p} / f \delta_{0}=0.2,0.4$ のいず れも最適值となる変形 $\delta_{\max } / f \delta_{0}=0.11$ を越えてから変形制御機構が 作用し, 最大せん断力 $\alpha_{\text {max }} /{ }_{f} \alpha_{0}$ が急激に増加する。柔要素に対する 変形制御機構の剛性の割合 $f d$ Kが大きいほど変形抑制効果が大きい が，応答せん断力 $\alpha_{\max } /{ }_{f} \alpha_{0}$ の増加も顕著になる。

以上より, 同じ最大変形に制御しようとする場合でも, 変形制御 機構の剛性が小さく, 変形制御機構を小さい変形から作用させる方 法では, 主架構に作用する最大せん断力の急激な増加は抑えられる が, 制振・免震効果が十分に発揮される範囲が狭くなる。一方, 変 形制御機構の作用し始める変形が大きく, 変形制御機構の剛性を大 きくする方法では, 制振・免震効果が十分に発揮できる範囲が広く なるが, 変形制御機構が作用すると主架構の最大せん断力が急激に 増加することが定量的にわかる。

\section{1 質点系変形制御構造モデルの概略検討手法及び検討例}

本章では, 1 質点系制振・免震構造モデルに, 変形制御機構を組 込んだ変形制御構造モデルの概略検討手法及び検討例を示す。

\section{1 1質点系変形制御構造モデルの概略検討手法}

制振・免震を想定した 1 質点系変形制御構造モデルの概略検討手 法を以下に示す。

手順1 建物諸元を設定する。

$<$ 建物緒元 $>$

制振 : 建物質量 $M$, 建物高さ $H$, 主架構の 1 次固有周期 $f T_{1}$

免震：上部構造質量 $M$ ，免震層の周期 $T_{1}$

手順(2) レベル 2 地震動に対して最大変形及び最大せん断力が低減 する最適なダンパー諸元を選定する。

<ダンパー諸元 $>$

制振・免震 : ダンパーの降伏せん断力係数 ${ }_{s} \alpha_{y}$

手順(3)レベル 2 の 2 倍の地震動に対する設計クライテリアを設定 し，設計クライテリアを満足するような変形制御機構の諸 元を決定する。

＜設計クライテリア $>$

制振：最大変形角 $R_{\text {max }}$ ，最大せん断力係数 $\alpha_{\text {max }}$

免震 : 免震層の最大変形 $\delta_{\text {max }}$, 最大せん断力係数 $\alpha_{\text {max }}$

$<$ 変形制御機構の諸元 $>$

制振 : 変形制御機構が作用し始める変形角 ${ }_{d} R_{g a p}$, 主架構の 剛性に対する変形制御機構の剛性の割合 $f d \kappa$

免震 : 変形制御機構が作用し始める変形 ${ }_{d} \delta_{g a p}$, 積層ゴムの 剛性に対する変形制御機構の剛性の割合 $f d \kappa$

\section{2 パラメータ概要}

最大変形 $\delta_{\max }$ と剛要素の降伏せん断力係数 ${ }_{s} \alpha_{y}$ の関係式である式 (14), 架構全体のせん断力係数 $\alpha_{\text {max }}$ と剛要素の降伏せん断力係数 ${ }_{s} \alpha_{y}$ の関係式である式(15)を用いることで, レベル 2 の 2 倍の地震 動に対する応答が設計クライテリアを満足するように変形制御機構 の諸元を決定する。また, これらの検討を通して変形制御構造の変 形とせん断力の関係について考察する。概略検討を行うにあたり，

\begin{tabular}{|c|c|c|}
\hline & 制振構造 & 免震構造 \\
\hline $\begin{array}{l}\text { 柔要素の } \\
\text { 1次固有周期 }{ }_{f} T_{1}(\mathrm{~s})\end{array}$ & 2.0 & 4.0 \\
\hline $\begin{array}{l}\text { 剛要素の } \\
\text { 降伏せん断力係数 }{ }_{s} \alpha_{y}\end{array}$ & $0.02,0.04,0.08,0.12,0.15$ & $0.01,0.02,0.04,0.06,0.10$ \\
\hline $\begin{array}{l}\text { 変形制御機構が作用し始める } \\
\text { 変形角 }{ }_{d} R_{g a p}(\mathrm{rad}) \\
\text { 変形 }{ }_{d} \delta_{g a p}(\mathrm{~cm}) \\
\end{array}$ & $\begin{array}{l}{ }_{d} R_{\text {gap }}(\mathrm{rad}) \\
1 / 500,1 / 200,1 / 120,1 / 100\end{array}$ & $\begin{array}{l}{ }_{d} \delta_{g a p}(\mathrm{~cm}) \\
10,20,30,40\end{array}$ \\
\hline $\begin{array}{l}\text { 柔要素の剛性に対する } \\
\text { 変形制御機構の剛性比 }{ }_{f d} \kappa\end{array}$ & $2.0,4.0$ & 10,20 \\
\hline $\begin{array}{l}\text { 入力エネルギーの } \\
\text { 速度換算值 } V_{E}(\mathrm{~cm} / \mathrm{s})\end{array}$ & $120(98), 240(195), 36$ & ※括弧内: $V_{D}$ \\
\hline
\end{tabular}

前節で示したように ${ }_{d} R_{g a p}$ 及び ${ }_{d} \delta_{g a p}$ を決定する必要がある。よって， 本章の検討においては ${ }_{d} R_{g a p}$ 及び ${ }_{d} \delta_{g a p}$ を変形制御機構のパラメータ として直接設定することとする。表 2 に，本章で用いる解析パラメ 一タを示す。制振構造モデルにおいては主架構の 1 次固有周期 ${ }_{f} T_{1}=$ $2.0 \mathrm{~s}$, 免震構造モデルにおいては免震層の周期 ${ }_{f} T_{1}=4.0 \mathrm{~s}$ を対象とす る。表中の括弧に示す $V_{D}$ は，下式 ${ }^{22)}$ より算出している。

$$
V_{D}=\frac{V_{E}}{1+3_{f} h+1.2 \sqrt{f h}}
$$

ここに, ${ }_{f} h$ : 主架構の減衰定数である。

\subsection{1 質点系変形制御構造モデルの概略検討例}

図 9 に, 1 質点系変形制御構造モデルの予測值による概略検討に 用いる最大せん断力と最大変形の関係を示す。図 9(a)に制振構造モ デルの場合（最大せん断力係数 $\alpha_{\max }$ と最大変形角 $R_{\max }$ の関係），図 9 (b)に免震構造モデルの場合（最大せん断力係数 $\alpha_{\max }$ と最大変形 $\delta_{\max }$ の関係）を示す。眓 9 には, 各 ${ }_{s} \alpha_{y}$ （表 1 参照）において変形 制御機構の諸元を変化させた時の予測值を示す。変形制御機構を組 込まない場合 (図中ではno controller と表記) は破線で表しており， 制振構造モデルでは ${ }_{s} \alpha_{y}=0.02 \sim 0.30$, 免震構造モデルでは ${ }_{s} \alpha_{y}=$ $0.01 \sim 0.15$ の範囲について， レベル 2 地震動（以降， $V_{E}=120 \mathrm{~cm} / \mathrm{s}$ と表記）及びレベル 2 の 2 倍の地震動（以降， $V_{E}=240 \mathrm{~cm} / \mathrm{s}$ と表記） に対する予測值を示している。変形制御機構を組込まない場合は, 各 ${ }_{s} \alpha_{y}$ における $V_{E}=120 \mathrm{~cm} / \mathrm{s}$ と $V_{E}=240 \mathrm{~cm} / \mathrm{s}$ の予測值を点線で繋い でおり, プロットは $\alpha_{y}$ を表している。変形制御機構を組込む場合 は実線で表しており，制振構造モデルでは ${ }_{s} \alpha_{y}=0.02 \sim 0.15$, 免震構 造モデルでは ${ }_{s} \alpha_{y}=0.01 \sim 0.10$ の範囲について, $V_{E}=240 \mathrm{~cm} / \mathrm{s}$ に対す る予測值を示している。 ${ }_{s} \alpha_{y}$ 及び ${ }_{f d} \kappa$ を一定として ${ }_{d} R_{g a p}\left({ }_{d} \delta_{g a p}\right)$ を変 化させた予測值の推移と, ${ }_{d} R_{\text {gap }}\left({ }_{d} \delta_{g a p}\right)$ 及び ${ }_{f d} \kappa$ を一定として ${ }_{s} \alpha_{y}$ を 変化させた予測值の推移を示しており, プロットは ${ }_{d} R_{g a p}\left({ }_{d} \delta_{g a p}\right) を$ 表している。対象とする $f_{d} \kappa$ は, 制振構造モデルでは $f d \kappa=2.0,4.0$, 免震構造モデルでは ${ }_{f d} \kappa=10,20$ であり, プロットで示す ${ }_{d} R_{g a p}$ 及び ${ }_{d} \delta_{\text {gap }}$ はそれぞれ ${ }_{d} R_{\text {gap }}=1 / 500,1 / 200,1 / 120,1 / 100 \mathrm{rad},{ }_{d} \delta_{\text {gap }}=10,20$, $30,40 \mathrm{~cm}$ (表 2 参照) である。図 10 に, 1 質点系変形制御構造モデ ルの概略検討結果として, 設計クライテリアを満足するケースに着 目した際の予測值及び解析值の結果を示す。図 10(a)に制振構造モデ ルの場合, 図 10(b)に免震構造モデルの場合を示す。

図 9, 10(a)より，制振構造モデルについて述べる。図 9(a)より，レ ベル 2 地震動に対して最適なダンパー量を選定するため, $V_{E}=120$ $\mathrm{cm} / \mathrm{s}$ に対する結果を見ると， $\alpha_{\text {max }}$ は ${ }_{s} \alpha_{y}=0.08,0.12$ で低減しており， 
$R_{\max }$ は ${ }_{s} \alpha_{y}=0.08$ 以上で $1 / 120 \mathrm{rad}$ を満足している。これより，レ心゙ ル 2 地震動に対する最適なダンパー量として,${ }_{s} \alpha_{y}=0.08$ を選定す る。レベル 2 の 2 倍の地震動に対する設計クライテリアを $R_{\max }=1 / 75$ $\mathrm{rad}, \alpha_{\text {max }}=1.0$ とし, ${ }_{s} \alpha_{y}=0.08$ の制振構造の $V_{E}=240 \mathrm{~cm} / \mathrm{s}$ に対する 結果を見ると, $R_{\max }=1 / 75 \mathrm{rad}$ を上回る結果となり, 過大な変形とな ってしまう。そのため, 変形制御機構を組込むことで $R_{\max }$ を低減さ せ， $\alpha_{\max }$ の増大も設計クライテリアを満足する結果となるよう変形 制御機構の諸元を決定する。図 9(a)より, ${ }_{s} \alpha_{y}=0.08$ の制振構造に ${ }_{d} R_{g a p}=1 / 500 \mathrm{rad}, f d \boldsymbol{K}=2.0$ の変形制御機構を組込むことで設計クラ イテリアを満足する結果となる。図 10(a)に, ${ }_{s} \alpha_{y}=0.08,{ }_{d} R_{g a p}=1 / 500$ $\mathrm{rad}, f d \boldsymbol{K}=2.0$ ケースに着目した概略検討結果を示している。図 10(a) より，予測值は解析值の傾向を安全側で概ね捉えられていることが わかる。ただし, 制振構造の場合, $\alpha$ の増大により変形制御機構を 組込んだ周辺架構に応力が集中寸ることで主架構が塑性化してしま う恐れがあるため, 主架構やダンパー諸元との関係等を考慮して, 適切に変形制御機構諸元を決定する必要があり, これに関しては部

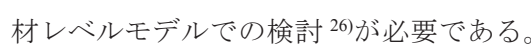

図 9, 10(b)より, 免震構造モデルについて述べる。図 9(b)より, レ ベル 2 地震動に対して最適なダンパー量を選定するため, $V_{E}=120$ $\mathrm{cm} / \mathrm{s}$ に対する結果を見ると， $\alpha_{\text {max }}$ はs $\alpha_{y}=0.02 \sim 0.06$ の範囲で低減 している。これより, レベル 2 地震動に対する最適なダンパー量と して, ${ }_{s} \alpha_{y}=0.02$ を選定する。レベル 2 の 2 倍の地震動に対寸る設 計クライテリアを $\delta_{\max }=60 \mathrm{~cm}, \alpha_{\max }=1.0$ とし, ${ }_{s} \alpha_{y}=0.02$ の免震構
造の $V_{E}=240 \mathrm{~cm} / \mathrm{s}$ に対する結果を見ると， $\delta_{\max }=60 \mathrm{~cm}$ を上回る結 果となり, 過大な変形となってしまう。そのため, 変形制御機構を 組込むことで $\delta_{\max }$ を低減させ， $\alpha_{\max }$ の増大も設計クライテリアを満 足する結果となるよう変形制御機構の諸元を決定する。図 9(b)より, ${ }_{s} \alpha_{y}=0.02$ の免震構造に ${ }_{d} \delta_{g a p}=30 \mathrm{~cm}, \quad f d \kappa=10$ の変形制御機構の変 形制御機構を組込むことで設計クライテリアを満足する結果となる。 図 10(b)には， ${ }_{s} \alpha_{y}=0.02 ，{ }_{d} \delta_{g a p}=30 \mathrm{~cm},{ }_{f d} \kappa=10$ ケースに着目した 概略検討結果を示している。図 10(b)より, 予測值は解析值の傾向を 安全側で概ね捉えられていることがわかる。

以上より, 提案した応答予測式を用いることで 1 質点系変形制御 構造モデルの応答特性を定性的かつ簡便に評価可能である。

\subsection{1 質点系変形制御構造モデルの応答特性に関する考察}

図 9 を用いて, 変形制御構造の応答特性について考察する。図 9 における変形制御構造の結果より，変形制御機構を組込むことで最 大変形は低減し, その傾向はダンパー量が小さい範囲において $f d \kappa$ が大きく ${ }_{d} R_{g a p}\left({ }_{d} \delta_{g a p}\right)$ が小さいほじ顕著となる。これより, レベル 2 程度の地震動に対して最適なダンパー量を選定し, そのダンパー量 を付与した制振構造及び免震構造に変形制御機構を組込むことで, 最大変形の低減効果湿著となることがわかる。また, 図 $9 よ り$, 免震構造における柔要素（積層ゴム）の剛性は制振構造における柔 要素 (主架構) の剛性と比較して小さく, 変形制御機構の岡性を大 きく設定できるため, 制振構造より免震構造の方が変形の低減効果

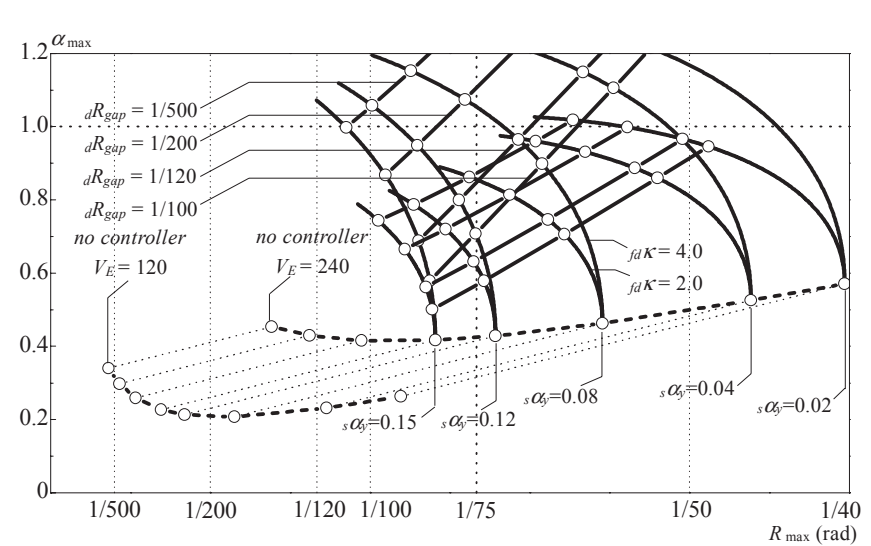

(a) 制振構造モデル $\left({ }_{f} T_{1}=2.0 \mathrm{~s}, n_{1}=1.0,{ }_{s} \alpha_{y}=0.02 \sim 0.15\right)$

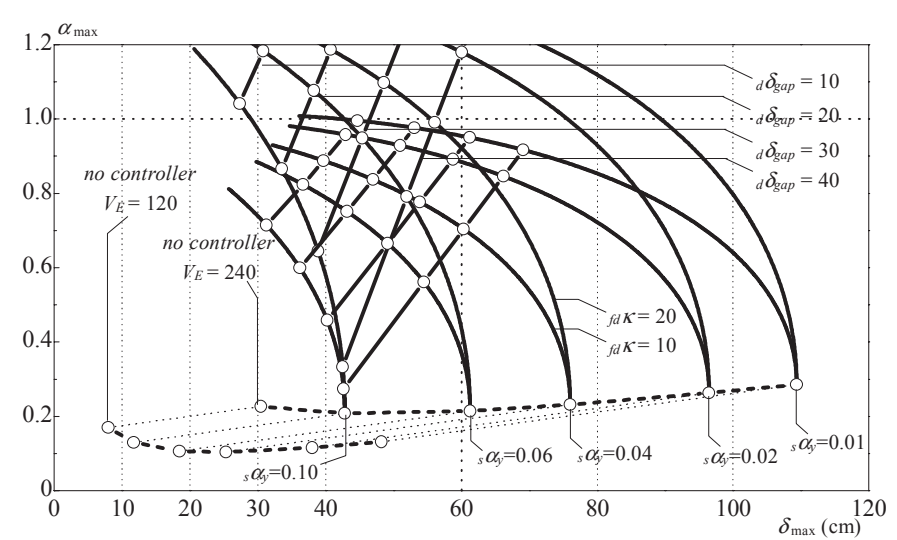

(b) 免震構造モデル（ ${ }_{f} T_{1}=4.0 \mathrm{~s}, n_{1}=1.0_{s} \alpha_{y}=0.01 \sim 0.10 ）$

図 91 質点系変形制御構造モデルの概略検討（ART KOBE）

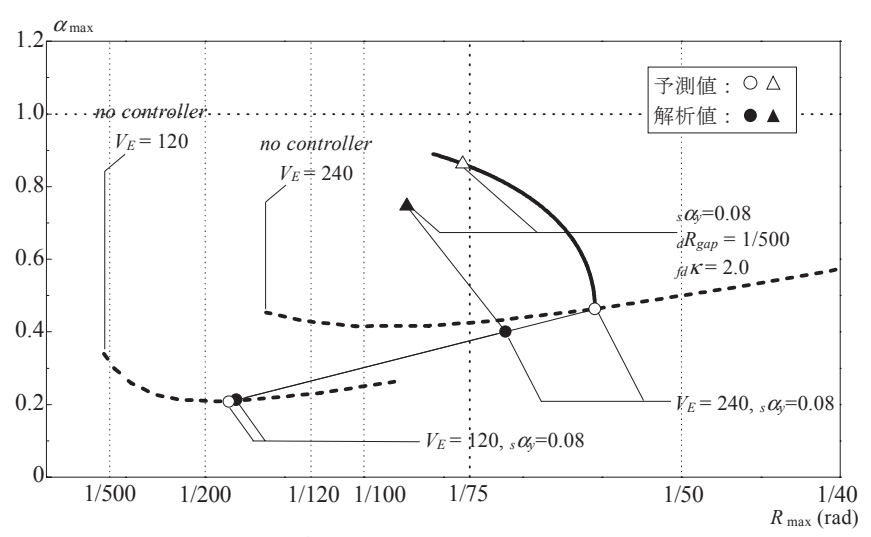

(a) 制振構造モデル $\left({ }_{f} T_{1}=2.0 \mathrm{~s}, n_{1}=1.0,{ }_{s} \alpha_{y}=0.08\right)$

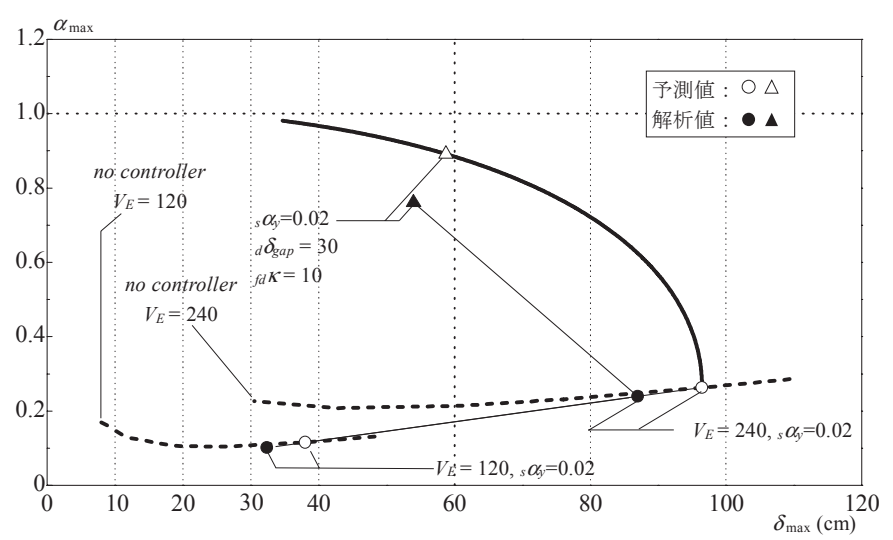

(b) 免震構造モデル $\left({ }_{f} T_{1}=4.0 \mathrm{~s}, n_{1}=1.0,{ }_{s} \alpha_{y}=0.02\right)$

図 101 質点系変形制御構造モデルの概略検討結果（ART KOBE） 
を期待できる結果となっている。しかし, 最大変形が低減する一方 で最大せん断力が増大寸ることにより, 変形制御機構による最大変 形の低減効果には限界があるため, 設計クライテリアを満足するよ うな応答とするためには最大変形と最大せん断力の関係から適切な 変形制御機構の諸元を設定する必要がある。一方, 図 9 の変形制御 機構を組込まない場合 (no controller) の結果より, 制振構造及び免 震構造においてダンパー量を増大させることで, 変形制御機構を組 込まずに最大変形を低減させることは可能である。しかし, 発生確 率が低くレベルの大きい地震動に対する応答低減効果を想定してダ ンパー量を増大させることは, 小さなレベルの地震動に対するダン パー性能を考えると効率的ではなく経済的な設計とは言えない。

以上のように，極大地震に対して制振構造及び免震構造の最大変 形を低減させる手段として, レベル 2 程度の地震動に対して選定し たダンパーと変形制御機構を組合せることやダンパー量を増大させ ることが挙げられるが，変形制御機構を組込む場合は最大変形低減 効果に伴う最大せん断力の増大, ダンパー量を増大させる場合は小 さな地震動レベルに対するダンパー効率の低下という課題があるた め, 建物の要求性能に応じて適切な機構を組込むことが重要である。

\section{5. まとめ}

本論文では, 高度な耐震性能を持った建物として採用される制振 構造及び免震構造に, 硬化型復元力特性を有寸る変形制御機構を組 込んだ変形制御構造の応答特性を定性的かつ簡便に評価することを 目的として，1 質点系モデルを対象としたエネルギーの釣合に基づ く応答評価法を変形制御構造に拡張し, 変形制御構造におけるエネ ルギーの釣合に基づく応答予測式を提案した。また，時刻歴応答解 析による結果を用いて応答予測式を検証した。さらに, 変形制御機 構を組込んだ制振構造及び免震構造を対象として, 応答予測式を用 いた概略検討手法及び検討例を示し, 変形制御構造の応答特性とし て変形低減に伴うせん断力増大の関係を明らかにした。以下に得ら れた知見を示す。

(1) 弾性挙動をする柔要素と弾塑性挙動をする剛要素からなる柔 剛混合構造に, 剛要素降伏後に剛性を持ち始める硬化型復元力 特性を示す変形制御機構を組込んだ変形制御構造を考え, 变形 の全てがダンパーの変形に寄与することを前提とし，1 質点系 モデルを対象とした応答予測式を導出した。

(2) 柔要素の 1 次固有周期 $T_{f} T_{1}$, 剛要素の降伏せん断力係数 ${ }_{s} \alpha_{y}$, 変形制御機構が作用し始める変形 ${ }_{d} \delta_{g a p} /{ }_{f} \delta_{0}$, 柔要素の剛性に 対する変形制御機構の剛性の割合 $f d \kappa$, 損傷に寄与するエネル ギー $E_{D}$ の速度換算值 $V_{D}$ をパラメータとした時刻歴応答解析 結果と, 提案した応答予測式による予測值の比較より, 予測值 は解析值を概ね捉えられることを確認した。これより，提案し た応答予測式を用いることで変形制御構造の応答特性の傾向 を捉えることができる。

(3) 変形制御構造において, エネルギー釣合に基づく応答予測式か ら, 変形制御機構の剛性 $f d \boldsymbol{K}$ が大きく, 変形制御機構が作用し はじめる変形 ${ }_{d} \delta_{g a p} /{ }_{f} \delta_{0}$ が小さいほど, 最大変形 $\delta_{\max } /{ }_{f} \delta_{0}$ の低 減傾向が顕著であり, 変形制御機構の剛性 $f d \kappa$ が大きいほじ, 最大せん断力 $\alpha_{\max } /{ }_{f} \alpha_{0}$ の増大傾向が顕著となることを示した。

(4) 制振構造及び免震構造を想定した変形制御構造の 1 質点系モデ
ルにおける概略検討手法及び検討例を示し，提案した応答予測 式による予測值と 1 質点系モデルによる解析值を用いることで, それぞれの構造において変形制御機構を組込んだ場合の応答 特性を評価できることを示した。

（5）レベル2程度の地震動に対して選定したダンパーと変形制御機 構を組合せることやダンパー量を増大させることで, 極大地震 に対して制振構造及び免震構造の最大変形を低減させること ができるが，変形制御機構を組込む場合は最大変形低減効果に 伴う最大せん断力の増大, ダンパー量を増大させる場合は小さ な地震動レベルに対するダンパー効率の低下という課題があ るため, 建物の要求性能に応じて適切な機構を組込むことが重 要であることを示した。

\section{謝辞}

本研究は, JFE スチール株式会社, JFE シビル株式会社, 東京理 科大学北村研究室による共同研究の成果の一部を用いたものです。 本論文の作成に当たっては, 東京理科大学大学院生の橋本奨吾氏の 協力を得ました。ここに記して感謝の意を表します。

\section{参考文献}

1) 原田幸博，秋山宏：エネルギ集中型柔剛混合骨組の耐震設計，日本建築 学会構造系論文集, 第 472 号, pp.57-66, 1995.6

2) 秋山宏 : 耐震性能の多様化に対応した耐震設計, 日本建築学会構造系論 文集，第 472 号，pp.85-90，1995.6

3）日本建築学会：1995 年兵庫県南部地震災害調査速報, pp.6-26, 1995.3

4) 岩田衛, 黄一華, 川合廣樹, 和田章: 被害レベル制御構造「Damage Tolerant Structure」に関する研究, 日本建築学会技術報告集, 第 1 号, pp.82-87, 1995.12

5) 北村春幸, 北村佳久, 伊藤優, 坂本光雄 : 適用建物調査に基づく日本の 応答制御構造の分析・評価, 日本建築学会技術報告集, 第 18 号, pp.55-60, 2003.12

6) 日本建築学会 : 2011 年東北地方太平洋沖地震災害調査速報, pp. 16-27, 2011.7

7) 日本建築学会：長周期地震動対策に関する公開研究集会, pp.39-138, $2011.3 \cdot$ p94, 2012.3

8) 内閣府, 首都直下地震対策, http://www.bousai.go.jp/jishin/syuto/index.htm (2013.3.22 閲覧)

9) 大阪府域内陸直下型地震に対する建築設計用地震動及び設計法に関す る研究会 : 大阪府域内陸直下型地震に対する建築設計用地震動および而 震設計指針（その 1 上町断層帯地震に対する大阪市域編), pp. II 1- II $68,2011.7$

10) 府省連携 革新的構造材料を用いた新構造システム建築物研究開発プ ロジェクト：新構造システム建築物設計・施工 (案), 新都市八ウジン グ協会, 日本鉄鋼連盟, 日本鋼構造協会, pp.1-6, 2009.3

11）小堀鐸二, 南井良一郎：地震による構造物の非線型振動について（その 2 構造物力学特性の人為的非線型化過程), 日本建築學會論文集, 第 52 号, pp.41-48, 1956.3

12) 渡辺宏一, 田村和夫 : ギャップ連層壁架構の地震応答特性, 日本建築学 会大会学術講演梗概集, B-2, 構造 II , 振動, 原子力プラント, pp.883-884, 1998.9

13）渡辺宏一，田村和夫：ギャップ連層壁架構の基本振動特性，第 10 回日 本地震工学シンポジウム, pp.2753-2758, 1998.11

14）渡辺宏一, 田村和夫, 中井正一 : ギャップ機構を用いた損傷分散型架構 の地震応答解析, 日本建築学会大会学術講演梗概集, B-2, 構造 II , 振 動, 原子力プラント, pp.635-636, 2010.7 
15) 渡辺宏一, 中井正一：硬化型復元力特性をもつ構造の最大層せん断力, 日本建築学会大会学術講演梗概集, B-2, 構造 II, 振動, 制振設計 - 性 能評価, pp.955-956, 2012.9

16）本間誠, 堀則男, 井上範夫 : エネルギー応答に基づいた地震を受ける鉄 筋コンクリート建物におけるダンパーと変形制御機構の設計, 日本建築 学会構造系論文集，第 618 号，pp.49-56，2007.8

17) 佐藤大樹, 船木尚己, 川股重也 : 硬化型非線形復元力をもつ制振架構の 振動応答, 日本地震工学シンポジウム論文集, 第 11 号, pp.1649-1654, 2002.11

18）南博之, 鈴木恭平, 多幾山法子, 大西良広, 林康裕 : パルス性地震動に 対する変形制御機構の効果に関する研究, 日本建築学会技術報告集, 第 39 号, pp.471-476, 2012.6

19）高橋武宏, 穴原一範, 深堀美英: 水平変位制御によって免震建物に発生 する衝撃力に関する実大実験と応答解析, 日本建築学会構造系論文集, 第 573 号, pp.223-230，2003.11

20) 飯場正紀, 緑川光正, 花井勉, 皆川隆之 : 変位抑制部材を用いた免震層 衝突時における免震住宅の地震時応答 $(1,2)$, 日本建築学会大会学術講 演梗概集， B-2，構造 II， 振動，原子カプラント, pp.425-428, 2004.8

21）中田信治, 花井勉, 飯場正紀, 小豆畑達哉, 梁川幸盛, 東田豊彦, 森俊 之, 緑川光正 : 変位抑制部材を有寸る戸建て免震住宅の地震時安全性に ついて $(1,2)$, 日本建築学会大会学術講演梗概集, B-2, 構造 II , 振動, 原子力プラント, pp.1001-1004, 2007.8

22）秋山宏: エネルギーの釣合に基づく建築物の耐震設計, 技報堂出版, 1999

23) 栗林晃司, 佐藤大樹, 北村春幸, 山口路夫, 西本晃治 : 実効変形を考慮 した履歷減衰型制振部材を有する鋼構造建物のエネルギーの釣合に基 づく応答予測法, 日本建築学会構造系論文集, 第 76 巻, 第 661 号, pp.543-552, 2011.3

24）北村春幸：性能設計のための建築振動解析入門，彰国社，pp.129-165, 2002

25) 北村春幸, 財津和康, 馬谷原伴恵: 主架構の塑性化を考慮した制振構造 物のエネルギーの釣合に基づく応答評価法，日本建築学会構造系論文集， 第 599 号, pp.71-78, 2006.1

26) 野村尚史, 佐藤大樹, 北村春幸, 植木卓也, 宮川和明: 高強度鋼と制振部 材及び変形制御機構を組合せた高耐震性能構造の部材レベルモデルに よる検討, 日本建築学会関東支部研究報告集, 2013.3

27) 野村尚史, 佐藤大樹, 北村春幸, 藤澤一善 : 建築構造用高強度鋼材 H-SA700 と制振部材を組合せた高耐震化中低層鋼構造建物の応答性状, 構造工学論文集, Vol.58B, pp179-187, 2012.3

28）免震部材標準品リスト 2009 , 社団法人 日本免震構造協会, pp.616, 2009.10

\section{附録 $\mathrm{A}$ エネルギー法における各要素のせん断力係数と最大変形の関係式}

附録 A では, 各要素のせん断力係数と最大変形の関係式を導出する。式(12) に式(13)を代入し， ${ }_{s} \alpha_{y} /{ }_{f} \alpha_{0}$ について解くと下式が得られる。

$$
\frac{{ }_{s} \alpha_{y}}{{ }_{f} \alpha_{0}}=\frac{1}{8 n_{1}} \cdot\left\{\frac{{ }_{f} \delta_{0}}{\delta_{\max }}-\frac{\delta_{\max }}{{ }_{f} \delta_{0}}-{ }_{f d} \kappa \cdot \frac{\delta_{\max }}{{ }_{f} \delta_{0}} \cdot\left(1-\frac{{ }_{d} \delta_{g a p}}{{ }_{f} \delta_{0}} \cdot \frac{{ }_{f} \delta_{0}}{\delta_{\max }}\right)^{2}\right\}
$$

式(15)に式(A1), (9), (13)を代入し， $\alpha_{\max } /{ }_{f} \alpha_{0}$ について解くと下式が得られる。

$$
\begin{aligned}
& \frac{\alpha_{\max }}{{ }_{f} \alpha_{0}}=\frac{{ }_{f} \alpha_{\max }}{{ }_{f} \alpha_{0}}+\frac{{ }_{s} \alpha_{y}}{{ }_{f} \alpha_{0}}+\frac{{ }_{d} \alpha_{\max }}{{ }_{f} \alpha_{0}} \\
& =\frac{1}{8 n_{1}} \cdot\left\{\frac{{ }_{f} \delta_{0}}{\delta_{\max }}+\left(8 n_{1}-1\right) \frac{\delta_{\max }}{{ }_{f} \delta_{0}}+{ }_{f d} \kappa \cdot \frac{\delta_{\max }}{{ }_{f} \delta_{0}} \cdot\left(1-\frac{{ }_{d} \delta_{g a p}}{{ }_{f} \delta_{0}} \cdot \frac{{ }_{f} \delta_{0}}{\delta_{\max }}\right) \cdot\left(8 n_{1}-1+\frac{{ }_{d} \delta_{g a p}}{{ }_{f} \delta_{0}} \cdot \frac{{ }^{f} \delta_{0}}{\delta_{\max }}\right)\right\}
\end{aligned}
$$

ここで，式(9)は式(13)を用いて下式で表される。

$$
\frac{{ }_{d} \alpha_{\max }}{{ }_{f} \alpha_{0}}={ }_{f d} \kappa \cdot\left(\frac{{ }_{f} \alpha_{\max }}{{ }_{f} \alpha_{0}}-\frac{{ }_{d} \delta_{g a p}}{{ }_{f} \delta_{0}}\right)={ }_{f d} \kappa \cdot \frac{\delta_{\max }}{{ }_{f} \delta_{0}} \cdot\left(1-\frac{{ }_{d} \delta_{g a p}}{{ }_{f} \delta_{0}} \cdot \frac{{ }_{f} \delta_{0}}{\delta_{\max }}\right)
$$

\begin{tabular}{|c|c|}
\hline$E(t)$ & : 入力エネルギー \\
\hline$E_{D}(t)$ & : 損傷に寄与するエネルギー $\left(E(t)-_{f} W_{d}(t)\right)$ \\
\hline$g$ & : 重力加速度 \\
\hline${ }_{f} h$ & : 主架構の減衰定数 \\
\hline$H$ & $: 1$ 質点系モデルの建物高さ \\
\hline$H_{e q}$ & $: 1$ 質点系モデルの等価建物高さ \\
\hline${ }_{d} k$ & : 変形制御機構の剛性 \\
\hline${ }_{f} k$ & : 柔要素の剛性 \\
\hline$M$ & : 建物質量 \\
\hline$n_{1}$ & : 剛要素の等価繰返し数 \\
\hline${ }_{f} Q_{\max }$ & : 柔要素の最大せん断力 \\
\hline${ }_{s} Q_{y}$ & : 剛要素の降伏せん断力, \\
\hline${ }_{d} Q_{\max }$ & : 変形制御機構の最大せん断力 \\
\hline$r_{q}$ & $:{ }_{f} Q_{\max }$ と ${ }_{s} Q_{y}$ の比 \\
\hline$R_{\max }$ & : 最大変形角 \\
\hline${ }_{d} R_{g a p}$ & : 変形制御機構が作用し始める変形角 \\
\hline${ }_{s} R_{y}$ & : 剛要素の降伏変形角 \\
\hline${ }_{p} S_{v}$ & : 地震動の擬似速度応答スペクトル \\
\hline$t_{m}$ & : 建物の最大応答值発生時刻 \\
\hline$t_{0}$ & : 地震動の継続時間 \\
\hline${ }_{f} T_{1}$ & : 柔要素の 1 次固有周期 \\
\hline$V_{D}$ & : 損傷に寄与するエネルギーの速度換算值 \\
\hline$V_{E}$ & : 入力エネルギーの速度換算值 \\
\hline & 地震動のエネルギースペクトル \\
\hline${ }_{f} W_{h}(t)$ & : 柔要素の減衰による消費エネルギー \\
\hline${ }_{f} W_{e}(t)$ & : 柔要素の弾性振動エネルギー \\
\hline${ }_{d} W_{e}(t)$ & : 変形制御機構の弾性振動エネルギー \\
\hline${ }_{s} W_{e}(t)$ & : 剛要素の弾性振動エネルギー \\
\hline${ }_{s} W_{p}(t)$ & : 剛要素の塑性履歴エネルギー \\
\hline$\alpha_{\max }$ & : 架構全体の最大せん断力係数 \\
\hline${ }_{d} \alpha_{\max }$ & : 変形制御機構の最大せん断力係数 \\
\hline${ }_{f} \alpha_{\max }$ & : 柔要素の最大せん断力係数 \\
\hline${ }_{f} \alpha_{0}$ & : 柔要素のみの場合の最大せん断力係数 \\
\hline${ }_{s} \alpha_{y}$ & : 剛要素の降伏せん断力係数 \\
\hline$\delta_{\max }$ & : 最大変形 \\
\hline${ }_{d} \delta_{g a p}$ & : 変形制御機構が作用し始める変形 \\
\hline${ }_{f} \delta_{0}$ & : 柔要素のみの場合の最大変形 \\
\hline${ }_{s} \delta_{y}$ & : 剛要素の降伏変形 \\
\hline${ }_{f d} \kappa$ & : 柔要素の剛性に対する変形制御機構の剛性の割合 \\
\hline
\end{tabular}

\section{附録 B 記号リスト}

(2013年 2 月 10 日原稿受理, 2013 年 6 月 20 日採用決定) 